\title{
Human papillomavirus in false negative archival cervical smears: implications for screening for cervical cancer
}

\author{
J M M Walboomers, A-M de Roda Husman, P J F Snijders, H V Stel, E K J Risse, \\ T J M Helmerhorst, F J Voorhorst, C J L M Meijer
}

\begin{abstract}
Aim-To assess the value of detecting human papillomavirus (HPV) DNA in false negative archival cervical smears in population based screening programmes for cervical cancer.

Methods-Cytomorphologically classified false negative archival Pap smears $(\mathbf{n}=27)$ taken from 18 women up to six years before cervical cancer was diagnosed were blindly mixed with 89 smears from hospital patients with a variety of gynaecological complaints and tested for HPV by the polymerase chain reaction (PCR). Corresponding cervical cancer biopsy specimens were also available for HPV analysis. Neither the examining cytopathologist nor the molecular biologist was aware of the study design.

Results-HPV DNA was detected in the smears of 16 patients with cervical cancer missed previously by cytology. HPV 16 and 18 were found predominantly in those smears taken up to six years before the diagnosis of cervical cancer. The smears of the two remaining patients were reclassified as inadequate for cytology or contained no suitable DNA for PCR. In 15 patients the same HPV type could be found i:l the smears and the cervical cancer biopsy specimens.

Conclusions-The results indicate that high risk HPV types can be detected in archival smears classified as false negative on cytology and that cytological screening errors may be reduced if combined with PCR testing for HPV.
\end{abstract}

(f Clin Pathol 1995;48:728-732)

Keywords: PCR, human papillomavirus, cervical cancer, screening.

In industrialised countries screening for cervical cancer is based on the presence of cytomorphologically abnormal epithelial cells in cervical smears. In spite of the success of cytomorphological examination in screening for cervical cancer, major drawbacks have been recognised. ${ }^{1}$ The percentage of false negative smears varies considerably between $15 \%$ and $50 \%,{ }^{2-5}$ while the number of false positive cervical smears is about $10 \%$. Therefore, the sensitivity of cytology in screening for cervical cancer is quite low (50-85\%) and the specificity is about $90 \%$. This unreliability is compensated for clinically by repeating the procedure within a rather short time interval, up to three years, ${ }^{6-8}$ depending on the results of the Pap smears. It has been shown recently that cervical cancer is strongly associated with the presence of high risk or oncogenic human papillomavirus (HPV) types (up to $100 \%$ ). ${ }^{910}$ In addition, a number of clinical follow up studies of women with cervical intraepithelial neoplasia (CIN) indicate that the presence of HPV DNA is of predictive value in progressive CIN disease. ${ }^{11-14}$

We have shown recently in a prospective study that only patients with cytomorphologically abnormal smears containing high risk HPV types are at high risk of developing progressive CIN. ${ }^{15}$ The aim of the present study was to determine whether HPV was present in 27 archival cervical smears taken up to six years before the women were diagnosed with cervical cancer.

\section{Methods}

STUDY DESIGN

From 1982 to 1993 a triannual cervical cancer screening programme was conducted in the district of Het Gooi, an area near Amsterdam, The Netherlands. Cervical smears were taken by several general practitioners and gynaecologists. Routine cytological screening was performed in the Department of Pathology of the Gooi Noord Hospital, Blaricum, The Netherlands, according to a modified Pap classification (KOPAC) ${ }^{16}$ : Pap 1, normal cells; Pap 2, inflammation; Pap 3a, mild and moderate dysplasia; Pap 3b, severe dysplasia; Pap 4, carcinoma in situ; and Pap 5, (micro)invasive cancer. With respect to quality control in the screening laboratory, retrospective analysis of cervical smears of 132 women who developed squamous cell carcinoma (confirmed by biopsy) revealed that for the 18 women who developed cervical cancer all 27 preceding smears were originally classified as normal (Pap 1). To ensure that the study was carried out blindly, the 27 smears were randomly mixed with 89 Pap smears obtained from 50 women (technical control group) attending the gynaecological outpatient department of the same hospital for a variety of gynaecological complaints including treatment of CIN lesions. In this latter group a reasonable HPV prevalence rate could be expected. ${ }^{9}$ Neither the investigating cytopathologist nor the molecular biologist was aware of the study design. Before starting the study, the 27 smears from the cervical cancer group were rescreened by two independent cytopathologists. The HPV testing laboratory 
personnel were unaware of the results of the original or the revised Pap test. Data were presented per patient after the HPV high risk types present had been identified. Details of the most recent smears are presented here.

\section{ISOLATION OF DNA FROM ARCHIVAL CERVICAL SMEARS}

The archival Pap smears were placed separately in $50 \mathrm{ml}$ xylene for 24 to 48 hours to remove the coverslip. The cells were scraped from the glass using a razor blade and collected in $1 \mathrm{ml}$ xylene. After a 45 minute incubation at room temperature to clean the cells from the remaining Depex mounting solution, the cells were pelleted by centrifugation and washed twice in $96 \%$ alcohol. The pellets were then air-dried at room temperature. DNA was subsequently isolated according a modified guanidine isothiocyanate GTC/silica beads protocol described by Boom et al. ${ }^{17}$ Briefly, cells were lysed in lysis buffer (guanidine isothiocyanate, Triton X-100, EDTA, Tris- $\mathrm{HCl}$ $(\mathrm{pH} 6.4)$ ) overnight or until the solution was clear. Silica beads were then added and the mixture was incubated for 60 minutes at room temperature and centrifuged. The resulting pellet was washed twice in wash solution (guanidine isothiocyanate, Tris- $\mathrm{HCl}(\mathrm{pH} \mathrm{6} 4)$ ) and once in $70 \%$ ethanol. After drying in air for 30 minutes, the nucleic acids were eluted from the beads by incubation with sterile water for 60 minutes at $58^{\circ} \mathrm{C}$. After centrifugation, the supernatant fluid was precipitated in ethanol, the resulting pellet was dissolved in $200 \mu \mathrm{l}$ TE and $10 \mu \mathrm{l}$ was used for PCR.

\section{ISOLATION OF DNA FROM CERVICAL CANCER BIOPSY SPECIMENS}

Formalin fixed, paraffin wax embedded biopsy specimens taken from 18 patients with cervical cancer were available for HPV analysis. Depending on the size of the sample, one to six sections $(4 \mu \mathrm{m})$ were cut and collected in $250 \mu \mathrm{l}$ digestion buffer $\left(1.5 \mathrm{mM} \mathrm{MgCl}_{2}, 50 \mathrm{mM} \mathrm{KCl}\right.$, $10 \mathrm{mM}$ Tris- $\mathrm{HCl}$ (pH 8.3), 0.45\% (v/v) Tween 20 , and $10 \mathrm{mg} / \mathrm{ml}$ proteinase $\mathrm{K}$ ). The samples were incubated overnight at $37^{\circ} \mathrm{C}$ followed by inactivation of proteinase $\mathrm{K}$ at $96^{\circ} \mathrm{C}$ for five minutes. The samples were centrifuged and $5 \mu \mathrm{l}$ of the supernatant fluid was used for PCR.

HPV DETECTION AND GENOTYPING BY PCR The detection of a broad spectrum of HPV genotypes was performed by general primer mediated PCR (GP-PCR), slightly modified from the previously described protocol. ${ }^{18}{ }^{19} \mathrm{Ex}-$ periments performed with different $\beta$-globin primers, spanning DNA fragments of different sizes, revealed that only relatively small DNA fragments ( 200 base pairs) could be efficiently amplified from archival Pap smears. Therefore, the HPV genotyping procedure commonly used in our laboratory ${ }^{19-21}$ was adapted. $\beta$ globin PCR positive samples were subjected to general HPV PCR in which a 150 base pair fragment is amplified. HPV $6 / 11,16,18,31$, and 33 type specific primers were designed which were internally localised in the HPV general primer mediated product and spanned no more than about 100 base pairs.

These PCRs were performed as described for the $\beta$-globin PCR. After gel electrophoresis, PCR products were blotted and hybridised with the HPV $6,11,16,18,31$, and 33 probe cocktail as described previously ${ }^{18}$ at a hybridisation and washing temperature of $65^{\circ} \mathrm{C}$. Samples which were positive for HPV DNA but could not be typed as HPV 6/11, 16, 18, 31 , or 33 were designated HPV X. A detailed optimal protocol for detecting HPV in archival smears is described elsewhere. ${ }^{22}$

\section{Results}

Of the 116 archival Pap smears analysed, two were $\beta$-globin PCR negative; therefore, 114 smears from 67 women were subjected to HPV analysis. Of these, 68 (59\%) were HPV positive. High risk HPV types $(16,18,31$; single and multiple infections) were detected in 41 $(35.9 \%)$ smears. In $25(21.9 \%)$ of the 114 smears HPV types other than $6,11,16,18$, 31 , or 33 were present.

Those patients with cancer were identified based on clinical data and included nine with one and a further nine with two archival Pap smears. Only one cervical smear had inadequate DNA ( $\beta$-globin PCR negative) for PCR and was not included in the analysis. Of the remaining 26 cervical smears, $24(92 \cdot 3 \%)$ were HPV positive. High risk HPV types (16, 18,31 ; single and double infections) were detected in $23(88.3 \%)$ smears. HPV X was found in one $(3.8 \%)$ case. In the nine patients with two smears the same HPV type(s) was present in both smears indicating persistent HPV infection. The prevalence of HPV is summarised in table 1 .

One of the smears from the control group was $\beta$-globin PCR negative and was not included in the analysis. A single smear was available from 28 patients. Two of these patients were treated

Table 1 Occurrence of HPV in false negative archival smears from women with cervical cancer and the control group, which comprised 50 women with a variety of gynaecological complaints

\begin{tabular}{|c|c|c|c|c|c|c|c|c|c|c|c|}
\hline \multirow{2}{*}{$\begin{array}{l}\text { Study } \\
\text { group }\end{array}$} & \multirow{2}{*}{$\begin{array}{l}\text { No. of } \\
\text { patients }\end{array}$} & \multirow{2}{*}{$\begin{array}{l}\text { No. of smears } \\
\text { per patient }\end{array}$} & \multirow{2}{*}{$\begin{array}{l}\% \text { High risk } \\
\text { positive patients }\end{array}$} & \multicolumn{7}{|c|}{$H P V^{\mathrm{a}}$} & \multirow{2}{*}{$\begin{array}{l}\text { Persistent HPV in } \\
\text { last two smears }\end{array}$} \\
\hline & & & & $6 / 11$ & 16 & 18 & 31 & 33 & $X$ & $M$ & \\
\hline \multirow[t]{2}{*}{ Cases } & 9 & 1 & $7 / 9(78 \%)^{b}$ & - & 3 & 2 & - & - & 1 & $1^{\mathrm{c}}$ & ND \\
\hline & 9 & 2 & $9 / 9(100 \%)$ & - & 3 & 2 & - & - & - & $4^{\mathrm{d}}$ & $9 / 9$ \\
\hline \multirow[t]{2}{*}{ Controls } & 28 & $15 \mathrm{f}$ & $5 / 28(17.9 \%)^{c}$ & - & 2 & 1 & 2 & - & 5 & - & ND \\
\hline & 22 & $2-5^{f}$ & $2 / 22(8 \cdot 6 \%)$ & - & 1 & 1 & - & - & 5 & - & $1 / 7^{\mathrm{g}}$ \\
\hline
\end{tabular}

a Result of single or last smear; ${ }^{\mathrm{b}}$ one PAP smear was unsuitable for testing (Pap 0) and one was $\beta$-globin PCR negative; ${ }^{\mathrm{c}} \mathrm{HPV}$ 6/11/16; ${ }^{\mathrm{d}} \mathrm{HPV} 16 / 31$ positive on four occasions; ${ }^{e}$ two HPV 16 positive patients had been treated for CIN III in the past; ${ }^{\mathrm{f}} 60$ smears in total; ${ }^{\mathrm{g}}$ persistent virus was HPV X; ND = not determined. 
Table 2 Characterisation of the cervical cancer patient group with cytomorphologically false negative archival Pap smears

\begin{tabular}{|c|c|c|c|c|c|c|c|}
\hline \multirow[b]{2}{*}{ Patient number } & \multicolumn{3}{|c|}{ First smear $(=\operatorname{Pap} 1)$} & \multicolumn{3}{|c|}{ Second smear (= Pap 1) } & \multirow[b]{2}{*}{ HPV type in biopsy specimen } \\
\hline & Time interval & $H P V$ & Revised cytology ${ }^{\mathrm{b}}$ & Time interval ${ }^{\mathrm{a}}$ & $H P V$ & Revised cytology ${ }^{\mathrm{b}}$ & \\
\hline 1 & 1 year & $\mathrm{ND}^{\mathrm{d}}$ & Pap 3b/4 & $\mathrm{ND}^{\mathrm{c}}$ & & & HPV 16 \\
\hline 2 & 3 months & HPV negative & Pap 0/0 & ND & & & $\mathrm{ND}(\beta-)$ \\
\hline 3 & 2 months & HPV 16 & Pap 3b/4 & ND & & & ND ( $\beta-)$ \\
\hline 4 & 3 months & HPV 18 & Pap 4/4 & ND & & & HPV 18 \\
\hline 5 & 1 year & HPV 16 & Pap 4/4 & ND & & & $\mathrm{ND}(\beta-)$ \\
\hline 6 & 1 year & HPV 18 & Pap 5/5 & ND & & & HPV 18 \\
\hline 7 & 1 year & HPV X & Pap 4/4 & ND & & & HPV X \\
\hline 8 & 2 years & HPV 16 & Pap 3b/3b & ND & & & HPV 16 \\
\hline 9 & 2 years & HPV $6,11,16$ & Pap $5 / 5$ & ND & & & HPV 16 \\
\hline 10 & 2 years & HPV $16 / 31$ & $\mathrm{Pap} 3 \mathrm{~b} / 3 \mathrm{~b}$ & 1 year & HPV $16 / 31$ & Pap 3b/3b & HPV 16,31 \\
\hline 11 & 3 years & HPV 16 & $\mathrm{Pap} 3 \mathrm{~b} / 3 \mathrm{~b}$ & 2 years & HPV 16 & $\mathrm{Pap} 3 \mathrm{~b} / 3 \mathrm{~b}$ & HPV 16 \\
\hline 12 & 4 years & HPV 16 & Pap 4/4 & 3 months & HPV 16 & Pap 4/4 & HPV 16 \\
\hline 13 & 4 years & HPV 18 & Pap 3b/4 & 2 years & HPV 18 & Pap 3b/4 & HPV 18 \\
\hline 14 & 4 years & HPV 31 & Pap 3a/3a & 3 years & HPV $16 / 31$ & Pap 3a/3a & HPV $16 / 31$ \\
\hline 15 & 5 years & HPV 16 & Pap 3b/3b & 3 months & HPV $16 / 31$ & Pap 3b/3b & HPV 16 \\
\hline 16 & 5 years & HPV 16 & $\mathrm{Pap} 3 \mathrm{~b} / 3 \mathrm{~b}$ & 2 years & HPV $16 / 31$ & Pap 3b/3b & HPV $16 / 31$ \\
\hline 17 & 6 years & HPV 16/18 & Pap 0/0 & 6 years & HPV 16 & Pap 0/0 & HPV 16 \\
\hline 18 & 7 years & HPV negative & Pap $0 / 0$ & 3 months & HPV 18 & Pap 4/4 & HPV 18 \\
\hline
\end{tabular}

a Time interval: period (years or months) before cervical cancer was diagnosed. ${ }^{b}$ Cytology was revised independently by two cytopathologists (separated by dashes). ${ }^{\mathrm{c}}$ Not determined because smears were not available. ${ }^{\mathrm{d}}$ Not determined because $\beta$-globin PCR was negative. ${ }^{\mathrm{e}}$ Biopsy specimens were histologically classified as poor to well differentiated squamous cell carcinoma.

for CIN III in the past and eight patients underwent subsequent uterus extirpation (five with leiomyoma, two with menstrual disorders, one with uterine prolapse). Twenty two patients contributed two to five smears (10 with leiomyoma, seven with endometrial disorders, four with uterine prolapse, and one unknown).

A high risk HPV type was detected in five $(17.9 \%)$ of 28 patients in the group with a single cervical smear. Smears from the two patients with CIN III lesions contained HPV 16. Of the 22 patients with two to five smears, two $(8.6 \%)$ had a high risk HPV type detected in their final smear. HPV X was detected in all three smears from one patient, which is suggestive of persistent infection. A consistent pattern was not detected in successive smears from most patients.

The results of HPV detection in the Pap smears and cervical cancer biopsy specimens, and the revised cytology of the 18 patients with cancer are summarised in table 2 . Of the nine patients with only one available Pap smear, the time of collection of the smear varied from two months to two years before cervical cancer was diagnosed. Smears from two patients were HPV negative. The smear from one of these patients was $\beta$-globin PCR negative (patient no. 1), while that from the other (patient no. 2) was reclassified twice as cytomorphologically inadequate (Pap 0/0). Of the remaining seven patients with one available cervical smear, HPV DNA (HPV 16 in three patients, HPV 18 in two, HPV 16, 6 and 11 in one, and HPV $X$ in one) was present up to two years before cervical cancer was diagnosed.

Of the nine patients who had two cervical smears taken, HPV DNA was detected up to six years before diagnosis of cervical cancer. In eight of these patients both smears were positive for high risk HPV types. In one patient (no. 17) both cervical smears were reclassed as inadequate for cytomorphological examination (Pap 0/0), although both smears were $\beta$-globin and HPV positive. One Pap smear over seven years old (from patient no. 18) was $\beta$-globin positive and HPV negative, and was reclassed as inadequate for cytomorphological examination (Pap 0/0). The adequate Pap smear taken three months before treatment for cervical cancer was started was positive for HPV 18. Finally, after excluding $\beta$-globin negative samples, no disagreement was found between HPV results for smears and biopsy specimens. Moreover, high risk HPVs were consistently present in the eight patients whose two smears contained amplifiable DNA.

\section{Discussion}

The number of deaths from cervical cancer has dropped dramatically in the past decade. ${ }^{2324}$ This is largely thought to be because of population based cervical cancer screening programmes using Pap smears for the detection of cytomorphologically abnormal cells. ${ }^{23-26}$ However, the Pap smear has not eradicated the disease in any screened population to date. Reports on failures of cytology to predict cervical cancer and cumulative false negative error rates for invasive cancer of up to $50 \%$ have been published. ${ }^{27}$ This complex cervical cancer detection system is prone to errors both in sampling (sampling error) and cytomorphological interpretation by the cytologist (screening error). ${ }^{1}$ Recent epidemiological and basic virological data strongly suggest that specific HPVs play an important role in the development of cervical cancer. ${ }^{2829}$ In general, HPV 6 and 11 have been associated with benign cervical lesions and are referred to as nononcogenic or low risk HPV types, whereas HPV 16 and 18, and to a lesser extent HPV 31, 33 and 35 , have been found mainly in cervical lesions with severe dysplasia (CIN III) and in more than $90 \%$ of cervical carcinomas. ${ }^{910203031}$ These latter HPVs are regarded as oncogenic or high risk HPV types. As HPV cannot be cultured in vitro, HPV genotypes must be identified by analysing nucleic acid sequences. The most sensitive HPV detection method is PCR which is theoretically able to detect one copy of a target sequence. ${ }^{32}{ }^{33}$ Because of this sensitivity and the distribution of the different HPV types in cytomorphologically normal, dysplastic and malignant cervical smears and tissue, ${ }^{9193031}$ the detection of HPV in cervical smears by PCR in conjunction with cytology could potentially 
improve screening for cervical cancer. With this in mind, we designed this retrospective study. Although patients with true negative smears would comprise the most appropriate control group, the expected prevalence of cervical cancer within the short time span studied (seven years) following a negative smear is so low (3\% in The Netherlands) that any epidemiological control group had to be very large to be informative. This was checked in a pilot study of 40 age matched patients with cytomorphologically confirmed true negative smears over seven years old. We only found one HPV 16 positive case and no abnormal cytology in the seven year follow up period (unpublished data).

HPV DNA was detected in the early smears of those women who subsequently developed cervical carcinoma. Interestingly, in one patient both smears were unsuitable for cytomorphological examination, indicating that testing for HPV can yield good results even in cytologically inadequate smears. Another important observation is that in the same patient the same HPV type was present in both the diagnostic biopsy specimen and the smears taken seven years before the diagnosis of cervical cancer. Moreover, if two smears were available, the same HPV type was found in both. By contrast, a variety of HPV types, which subsequently disappeared during follow up, were detected in the control group. These patients did not develop cervical cancer.

This fits the hypothesis that persistent infection with high risk HPV types is a prerequisite for the development of cervical cancer $^{29}$ and suggests that the continuous detection of a high risk HPV type in cervical smears is a significant risk factor for the development of invasive cervical cancer. Indeed, we have recently shown, in a longitudinal, noninterventional, colposcopic study in 327 women presenting with abnormal cytology, that progression to cancer was only found in those women who had a persistent HPV infection. ${ }^{1534}$

Re-examination of smears taken from a woman who subsequently developed cervical cancer revealed that nearly all of the smears contained abnormal cells. Therefore, the detection of high risk HPV types, in conjunction with cytology, could potentially reduce the number of erroneously classified cervical smears substantially. Cytologically negative, HPV positive smears should be rescreened, thereby increasing the detection rate of abnormal cervical cells. For the Dutch population over 35 years of age, this means that $2 \%$ (the prevalence of high risk HPV types in this group) of cytomorphologically normal smears would be re-examined. ${ }^{21}$ In a preliminary experiment cytomorphologically abnormal cells were detected in smears from about $50 \%$ of women with normal cytology and oncogenic HPV types on rescreening (Meijer, personal communication).

As invasive cervical cancer takes about $12 \cdot 7$ years to develop, ${ }^{35}$ the screening interval for women with cytomorphologically normal, HPV negative smears aged over 35 years could be increased to more than three years, ${ }^{3637}$ as is presently the case in The Netherlands. In this way, more effective screening with fewer screening errors could be attained. Analyses of the cost of these alternative screening approaches are currently under way.

This work was supported by grants from the Prevention Fund (28-1502.2) and the Dutch Cancer Society "Koningin Wilhel mina Fonds" IKA-VU-91-10, The Netherlands.

PJF Snijders is a fellow of the Royal Netherlands Academy of Arts and Sciences. We are indebted to Sandra de Kruijf and Willemijn Lodder for excellent technical assistance and Drs $P$ van Diest and $P$ van der Valk for critical reading of the manuscript.

1 Koss LG. The papanicolaou test for cervical cancer detection: a triumph and a tragedy. $\mathcal{F A M A} 1989 ; 261: 737-43$.

Devesa SS, Young JL, Brinton LA, Fraumeni JF. Recent trends in cervix uteri cancer. Cancer 1989;64:2184-90.

3 Coppleson LW, Brown B. Estimation of the screening error rate from the observed detection rates in repeated cervical cytology. Am f Obstet Gynecol 1974;119:953-8.

4 Boyes DA. The value of a Pap smear program and suggestions for its implementation. Cancer 1981;48:613-21.

5 Miller AB, Lindsay J, Hill GB. Mortality from cancer of the uterus in Canada and its relationship to screening for cancer of the cervix. Int $\mathcal{f}$ Cancer 1976;17:602-12.

6 IARC working group on evaluation of cervical cancer screening programmes. Screening for squamous cervical cancer: duration of low risk after negative results of cervical cytology and its implication for screening policies. $B M \mathcal{F} 1986$; 293:659-64.

7 Wied GL, Bartels PH, Bibbo M, Bolbler CM. Frequency and reliability of diagnostic cytology of the female genital and reliability of diagnostic cytol.

8 Richart RM, Barron BA. Screening strategies for cervical cancer and cervical intraepithelial neoplasia. Cancer 1981 47:1176-81

9 Van den Brule AJC, Walboomers JMM, du Maine $\mathbf{M}$ Kenemans P, Meijer CJLM. Difference in prevalence of human papillomavirus genotypes in cytomorphologically normal cervical smears is associated with a history of cervical intraepithelial neoplasia. Int f Cancer 1991;48: 404-8.

10 Resnick RM, Cornelissen MTE, Wright DK, Eichinger GH, Fox HS, ter Schegget J, et al. Detection and typing of human papillomavirus in archival cervical cancer speci-
mens by DNA amplification with consensus primers. $f$ mens by DNA amplification with

11 Kataja V, Syrjanen S, Mantyjarvi R, Yliskoski M, Saarikoski $S$, Syrjanen K. Prognostic factors for cervical human papillomavirus infections. Sex Trans Dis 1992;19:154-60.

12 Syrjanen K, Mantyjarvi R, Vayrynan M, Syrjanen S, Parkkinen $\mathrm{S}$, Yliskoski $\mathrm{M}$, et al. Assessing the biological potential of human papillomavirus infections in cervical carcinogenesis. In: Steinberg BM, Brandsma JL, Taichman LB, eds. Papillomaviruses. Vol 5 of Cancer cells. Cold Spring Harbor: Cold Spring Harbor Laboratory Press, 1987:281-9.

13 Campion H J, McCance D J, Cuzick J, Singer A. Progressive potential of mild cervical atypia: prospective cytological, potential of mild cervical atypia: prospective cytological,
colposcopic and virological study. Lancet 1986;ii:237-40.

14 Gaarenstroom KN, Melkert P, Walboomers JMM, Van den Brule AJC, Bommel PFJ van, Meijer CJLM, et al. Human papillomavirus DNA and genotypes: prognostic factors for progression of cervical intraepithelial neoplasia. Int $\mathcal{F}$ Gynecol Cancer 1994;4:73-8.

15 Remmink AJ, Walboomers JMM, Helmerhorst TJM, Voorhorst FJ, Rozendaal L, Risse EKJ, et al. The presence of persistent high risk HPV genotypes in dysplastic cervical lesions is associated with progressive disease: natural history up to 36 months. Int $\mathcal{F}$ Cancer, in press.

16 Vooys GP. De advisering bij afwijkende bevindingen van cytologisch onderzoek van de cervix uteri. Ned Tijdsch Geneeskd 1981;131:1662-3

17 Boom R, Sol CJA, Salimans MMM, Jansen CL, WertheimVan Dillen RME, Van der Noordaa J. Rapid and simple method for purification of nucleic acids. $\mathcal{f}$ Clin Microbio 1990;28:495-503.

18 Snijders PJF, Van den Brule AJC, Schrijnemakers HFI Snow G, Meijer CJLM, Walboomers JMM. The use of general primers in the polymerase chain reaction permits the detection of a broad spectrum of human papillomavirus genotypes. F Gen Virol 1990;71:173-81.

19 Van den Brule AJC, Meijer CJLM, Bakels V, Kenemans P, Walboomers JMM. Rapid detection of human papillomavirus in cervical smears by combined general primermediated and type-specific polymerase chain reaction. $\mathscr{f}$ Clin Microbiol 1990;28:2739-43.

20 de Roda Husman AM, Walboomers JMM, Meijer CJLM, Risse EKJ, Schipper MEI, Helmerhorst ThM, et al. Analysis of cytomorphologically abnormal cervical smears for the presence of 27 mucosotropic human papillomavirus genotypes using polymerase chain reaction. Int $\mathrm{f}$ Cancer 1994;56:802-6.

21 Melkert PJW, Hopman E, Van den Brule AJC, Risse EKJ, Diest PJ van, Bleker OP, et al. Prevalence of HPV in cytomorphologically normal cervical smears, as determined by the polymerase chain reaction, is age-dependent. Int $\mathcal{F}$ Cancer 1993;53:919-23.

22 de Roda Husman AM, Snijders PJF, Stel HV, Van den Brule AJC, Meijer CJLM, Walboomers JMM. Processing of long stored archival cervical smears for human papillomavirus 
detection by the polymerase chain reaction. $\mathrm{Br} \mathcal{F}$ Cancer; in press.

23 Van der GraafY. Screening for cervical cancer; The Nijmegen project [dissertation]. Nijmegen: Univ of Nijmegen, 1987.

24 Cramer DW. The role of cervical cytology in the declining morbidity and mortality of cervical cancer. Cancer 1974; 34:2018-27.

25 Miller AB. Evaluation of the impact of screening for cancer of the cervix. In: Hakama M, Miller AB, Day NEW, eds. Screening for cancer of the uterine cervix. Lyon: IARC, 1986: 149-60.

26 Christopherson WM, Lundin FE, Mendez WM, Perker JE. Cervical cancer control: A study of morbidity and mortality trends over a 21 year period. Cancer 1976;35:1357-66.

27 Van der Graaf Y, Vooijs GP. False negative rate in cervical cytology. f Clin Pathol 1987;40:438-42.

28 Munoz N, Bosch FX, Sanjose S, Tafur L, Izarzugaza I, Gili $M$, et al. The causal link between human papillomavirus and invasive cervical cancer: a population-based case-control invasive cervical cancer: a population-based case-control

29 Zur Hausen H. Human papillomaviruses in the pathogenesis Zur Hausen H. Human papillomaviruses in the
of anogenital cancer. Virology 1991;184:9-13.

30 Bergeron C, Barrasso R, Beaudenon S, Flamant P, Croissant $O$, Orth $G$. Human papillomaviruses associated with cervical intraepithelial neoplasia. Great diversity and distinct distribution on low- and high-grade lesions. Am $\mathcal{F}$ Surg Pathol 1992;16:641-9.

31 Lorincz AT, Reid R, Jenson AB, Greenberg MD, Lancaster W, Kurman RI. Human papillomavirus infection of the cervix: relative risk associations of 15 common anogenital types. Obstet Gynecol 1992;79:328-37.
32 Saiki RH, Gelland DH, Stoffel S, Scharf S J, Higuchi R, Horn GT, et al. Primer directed enzymatic amplification of DNA with a thermostable DNA polymerase. Science 1987;239:487-91.

33 Manos MM, Wright DK, Lewis AJD, Broker TR, Wolinsky $\mathrm{SM}$. The use of polymerase chain reaction amplification for the detection of genital human papillomaviruses. In: for the detection of genital human papillomaviruses. In: Furth M, Greaves M, eds. Molecular diagnostics of human cancer. Vol 7 of Cancer cells. Cold Spring Har

34 Kenemans P. HPV genotypes as a prognostic factor for progression to cervical carcinoma in young women. Eur f Obstet Gynecol Reprod Biol 1994;55:24-5.

35 van Ootmarssen GH, Habema JDF, van Ballegooijen $M$. Predicting mortality from cervical cancer after negative smear test results. BMf 1992;305:449-53.

36 Meijer CILM, Van den Brule AJC, Snijders PJF, Helmerhorst ThJM, Kenemans P, Walboomers JMM Detection of human papillomavirus in cervical scrapes by the polymerase chain reaction in relation to cytology: possible polymerase chain reaction in relation to cytology: possible implication for cervical cancer screening. In: Munoz N, Bosch FX, Shah KV, Meheus A, eds. The epidemiology of 1992:271-80

37 Walboomers JMM, de Roda Husman AM, Van den Brule AJC, Snijders PJF, Meijer CJLM. Detection of genital human papillomavirus infections. Critical review of methods and prevalence studies in relation to cervical cancer. In: Stern PL, Stanley $\mathrm{H}$, eds. Human papillomavirus and cervical cancer. Biology and immunology. Oxford: Oxford University Press, 1994:41-71. 